\title{
Association between infection early in life and mental disorders among youth in the community: a cross-sectional study
}

\author{
Renee D Goodwin
}

\begin{abstract}
Background: The objective of this study was to examine the association between infection early in life and mental disorders among youth in the community.

Methods: Data were drawn from the MECA (Methods in Epidemiology of Child and Adolescent psychopathology), a community-based study of 1,285 youth in the United States conducted in 1992. Multiple logistic regression analyses were used to investigate the association between parent/caregiver-reported infection early in life and DSM/DISC diagnoses of mental disorders at ages 9-17.

Results: Infection early in life was associated with a significantly increased odds of major depression $(\mathrm{OR}=3.9)$, social phobia $(O R=5.8)$, overanxious disorder $(O R=6.1)$, panic disorder $(O R=12.1)$, and oppositional defiant disorder $(\mathrm{OR}=3.7)$.

Conclusions: These findings are consistent with and extend previous results by providing new evidence suggesting a link between infection early in life and increased risk of depression and anxiety disorders among youth. These results should be considered preliminary. Replication of these findings with longitudinal epidemiologic data is needed. Possible mechanisms are discussed.
\end{abstract}

\section{Background}

In recent years, there is increasing interest in determining linkages between mental health in early life and risk of poor mental health in adolescence and adulthood [1-5]. Literature to date generally supports a relationship between mental health and early behavioral tendencies and mental health status and psychiatric outcomes later in life. More recently, there is growing interest in extending this link by investigating whether and to what degree physical health in early life is predictive of later mental health and functional outcomes [5,6]. In particular, there has been growing interest in the linkages between early immune functioning and later health outcomes [7-9].

Previous clinical and epidemiologic data have demonstrated links between early immune functioning and later physical health outcomes [10-12]. In general, severe

Correspondence: rdg66@columbia.edu

Department of Epidemiology, Mailman School of Public Health, Columbia University, 722 West 168th Street, Rm 1505, New York, NY 10032, USA infection has been shown to be associated with increased risk of physical health problems in adolescence and later adulthood. For instance, youth with early respiratory infections have increased risk of respiratory disease (e.g., asthma) in later life [13-15]. Yet, this is not the outcome in all cases, and severity of early insult/illness may play a significant role in this determination.

More recently, there are converging data from several sources suggesting that infection early in life may also be related to poor mental health outcomes. For instance, data from adult cross-sectional epidemiologic samples showing higher rates of schizophrenia and other psychotic disorders among those exposed to early infection [16-18]. More recently, this link has been extended to anxiety disorders among youth [19-23]. Specifically, there is increasing evidence of a relationship between infection early in life and increased likelihood of anxiety disorders later in childhood and adulthood. This association is supported by evidence from two sources. First, there are data to suggest an association between 
streptococcal infection and increased risk of obsessivecompulsive disorder (OCD) in clinical samples [20-23]. Second, data from community-based samples suggest that there is a relationship between early respiratory disease and increased risk of panic-related disorders during young adulthood [19].

There are also convergent data from laboratory studies suggesting that infection may lead to changes in immune function (e.g., shift from $\mathrm{T} 1$ to $\mathrm{T} 2$ immune functioning) and that these may relate to increased depressive symptoms and behaviors [24-26].

In sum, there is growing interest and evidence regarding an association between infection early in life and increased risk of later poor mental health outcomes. Yet, several questions remain unanswered. First, it is not known whether there is an association between early infection and increased risk of any mental disorders, or if the risk specific to only some disorders. Second, it is not clear whether the association between early infection and later increased risk of mental disorders applies to the community, or whether it is only evident in selected clinical samples.

Against this background, the goal of the current study is to determine the association between infection early in life and the risk of mental disorders among youth in the community. The study will: (1) investigate the association between early infection and the odds of any mental disorders in youth, compared to youth without early infection; (2) investigate the association between early infection and specific mental disorders in youth, compared with those without early infection.

\section{Methods \\ Sample}

Data were drawn from the Methods in Epidemiology of Child and Adolescent psychopathology (MECA) study, a cross-sectional epidemiologic study designed to gather data on childhood psychopathology with structured clinical interviews of both the child and parent (U01MH46718) [27,28]. The MECA study was conducted at 4 sites in the United States in which 1,285 youth were surveyed: Columbia University, Emory University, the University of Puerto Rico, and Yale University.

\section{Measures}

In the MECA Study, one child and one parent/guardian in each family were interviewed and detailed information on the child was obtained, including child psychiatric diagnoses (measured by NIMH's DISC 2.3, including major depression, dysthymia, separation anxiety disorder, panic disorder, social phobia, specific phobia, overanxious disorder, avoidant disorder, attention deficit hyperactivity disorder, conduct disorder, oppositional defiant disorder and substance use disorders). Further details of the MECA methods are available elsewhere $[29,30]$.

\section{Early infection}

A question as asked to all parents/caregivers of the respondent whether the child had experienced, "a severe infection during the first year of life, needing antibiotics." Responses were yes/no.

\section{Analytic strategy}

First, Pearson's Chi-Square tests were used to examine differences in age, sex and socioeconomic status between youth with and without early infection. All tests were two-tailed and significance was set at .05. Next, multiple logistic regression analyses were conducted to determine the relationship between early infection and mental disorders. In conducting these analyses, unadjusted odds ratios were computed, with $95 \%$ confidence intervals.

\section{Approval}

This research project was in compliance with the Helsinki Declaration. Columbia University Institutional Review Board granted ethical approval of this study.

\section{Results}

There were no statistically significant differences between youth with and without early infection in terms of age (12.9 (2.2) vs. 12.9 (2.6) years, p = .96), sex (57.1\% vs. $53.0 \%$ female, $\mathrm{p}=.8$ ) or low socioeconomic status $(14.3 \%$ vs. $15.0 \%, \mathrm{p}=.9)$.

Table 1 shows the results of bivariate associations between early infection and mental disorders during childhood. Major depression, panic disorder, social phobia, overanxious disorder and oppositional defiant disorder (ODD) were significantly more common among youth with a history of infection, compared to youth without infection.

Among youth with early infection, 35.7\% (5) met criteria for no mental disorder diagnosis, $7.1 \%$ (1) had one, $21.4 \%$ (3) had two, $7.1 \%$ (1) had four, $7.1 \%$ (1) had five, $14.3 \%$ (2) had six and $7.1 \%$ (1) met criteria for eight diagnoses.

\section{Discussion}

These results suggest a possible link between early infection and increased odds of mental disorders among youth in the community. Specifically, the data suggest that early severe infection may be related to increased likelihood of major depression, overanxious disorder, separation anxiety, and specific phobia, compared to those without infection, who were not exposed to infection early in life. Adjustment for confounding factors 
Table 1 Association between infection early in life and mental disorders among youth in the community

\begin{tabular}{|c|c|c|c|}
\hline & $\begin{array}{l}\text { No infection } \\
(n=1265)\end{array}$ & $\begin{array}{l}\text { Infection } \\
(\mathrm{n}=14)\end{array}$ & $\begin{array}{l}\mathrm{OR}^{*} \\
(95 \% \mathrm{Cl})\end{array}$ \\
\hline Any mental disorder & $\begin{array}{l}31.8 \% \\
(404)\end{array}$ & $\begin{array}{l}64.3 \% \\
(9)\end{array}$ & $\begin{array}{l}3.9 \\
(1.3,11.6)\end{array}$ \\
\hline Major depression & $\begin{array}{l}6.9 \% \\
(88)\end{array}$ & $\begin{array}{l}21.4 \% \\
(3)\end{array}$ & $\begin{array}{l}3.7 \\
(1.0,13.4)\end{array}$ \\
\hline Dysthymia & $\begin{array}{l}4.3 \% \\
(55)\end{array}$ & 0 & $\mathrm{n} / \mathrm{a}$ \\
\hline Separation anxiety disorder & $\begin{array}{l}6.5 \% \\
(83)\end{array}$ & $\begin{array}{l}7.1 \% \\
(1)\end{array}$ & $\begin{array}{l}1.1 \\
(0.1,8.5)\end{array}$ \\
\hline Panic disorder & $\begin{array}{l}0.6 \% \\
(8)\end{array}$ & $\begin{array}{l}7.1 \% \\
(1)\end{array}$ & $\begin{array}{l}12.1 \\
(1.4,104.2)\end{array}$ \\
\hline Social phobia & $\begin{array}{l}14.7 \% \\
(187)\end{array}$ & $\begin{array}{l}50.0 \% \\
(7)\end{array}$ & $\begin{array}{l}5.8 \\
(2.0,16.7)\end{array}$ \\
\hline Overanxious disorder & $\begin{array}{l}11.0 \% \\
(140)\end{array}$ & $\begin{array}{l}42.9 \% \\
(6)\end{array}$ & $\begin{array}{l}6.1 \\
(2.1,17.7)\end{array}$ \\
\hline Obsessive or compulsive disorder & $\begin{array}{l}2.8 \% \\
(35)\end{array}$ & $\begin{array}{l}7.1 \% \\
(1)\end{array}$ & $\begin{array}{l}2.7 \\
(0.3,21.3)\end{array}$ \\
\hline Generalized anxiety disorder & $\begin{array}{l}4.6 \% \\
(59)\end{array}$ & $\begin{array}{l}14.3 \% \\
(2)\end{array}$ & $\begin{array}{l}3.4 \\
(0.7,15.6)\end{array}$ \\
\hline Avoidant disorder & $\begin{array}{l}4.6 \% \\
(59)\end{array}$ & $\begin{array}{l}14.3 \% \\
(2)\end{array}$ & $\begin{array}{l}3.4 \\
(0.7,15.6)\end{array}$ \\
\hline Specific phobia & $\begin{array}{l}21.6 \% \\
(275)\end{array}$ & $\begin{array}{l}21.4 \% \\
(3)\end{array}$ & $\begin{array}{l}1.0 \\
(0.3,3.6)\end{array}$ \\
\hline $\begin{array}{l}\text { Attention deficit/hyperactivity } \\
\text { Disorder }\end{array}$ & $\begin{array}{l}6.4 \% \\
(81)\end{array}$ & $\begin{array}{l}14.3 \% \\
(2)\end{array}$ & $\begin{array}{l}2.4 \\
(0.5,11.1)\end{array}$ \\
\hline Conduct disorder & $\begin{array}{l}5.8 \% \\
(74)\end{array}$ & 0 & $\mathrm{n} / \mathrm{a}$ \\
\hline Oppositional defiant disorder & $\begin{array}{l}6.9 \% \\
(88)\end{array}$ & $\begin{array}{l}21.4 \% \\
(3)\end{array}$ & $\begin{array}{l}3.7 \\
(1.0,13.4)\end{array}$ \\
\hline $\begin{array}{l}\text { Any substance } \\
\text { use disorder }\end{array}$ & $\begin{array}{l}2.2 \% \\
(28)\end{array}$ & On/a & \\
\hline
\end{tabular}

Bold $=p<.05$

*ORs are unadjusted

suggested that this link was not attributable to differences in sociodemographic characteristics.

These data suggest that there is an association between severe infection early in life and increased risk of depressive and anxiety disorders during childhood and adolescence. The mechanism of this association cannot be determined on the basis of these data alone, though three main possibilities seem plausible. It may be that experience of a severe infection leads to functional impairment or limitations later in life such that demoralization and depression are more likely to result. For instance, several studies have shown linkages between physical illnesses and post-traumatic stress disorder [31] and depressive disorders [32]. It is also possible that early infection leads to biochemical changes which result in neurobiological differences that increase the risk of depression onset. This explanation is consistent with laboratory findings showing linkages between immune functioning and depressive behaviors [24-26]. It is also consistent with literature on sickness behavior and depressive symptoms [33,34]. Alternatively, it may be that there are common factors that lead to increased likelihood of having both infection in early life and mental disorders during childhood. These include parental psychopathology or potentially adverse childhood exposures such as childhood abuse or childhood neglect both of which are associated with mental disorders in childhood,[35,36] though less is known specifically about linkages between childhood abuse and infection early in life. Finally, it is also possible that severe infection during youth lead to increased anxiety disorders among vulnerable parents and that this correspondingly increased the risk of anxiety and depressive disorders among youth, as parental and offspring internalizing disorders are linked [37].

\section{Study limitations}

There are several limitations of this study that need to be considered when interpreting results, which should be viewed as preliminary until replication. First, the measure of early infection was very crude, as it was by parent report only and therefore could be influenced by 
recall or misinformation bias. As reporting was retrospective, failure to recall early infection is possible, and it is conceivable that parents of youth with more serious mental disorders may be more likely to recall problems such as illness during early years of life. Ideally, a future study that uses prospective data with corroborative information from physical examination, laboratory tests, medical records, or data on type of treatment received can replicate these findings. Also, use of a larger sample to test this hypothesis is recommended as cell size is small in several analyses and may have limited our ability to detect statistical significance in some comparisons.

\section{Conclusions}

Results of this study provide preliminary results suggesting early severe infection in childhood is associated with an increased risk of depressive and anxiety disorders during childhood and adolescence. Future studies with more rigorous measurement of infection are needed for replication of these results and to understand potential mechanisms of the observed link.

\section{Abbreviations}

MECA: Methods in Epidemiology of Child and Adolescent psychopathology; DSM: Diagnostic Statistical Manual; DISC: Diagnostic Interview Schedule for Children; OR: odds ratio; OCD: obsessive-compulsive disorder; NIMH: National Institute of Mental Health; ODD: oppositional defiant disorder.

\section{Acknowledgements}

The author would like to thank Christopher Lowry, M.D. and Graham Rook, M.D. for helpful comments on an earlier version of this manuscript. This work was supported by NIMH grant \# MH 63746. The funding organization did not participate in the design or conduct of the study; collection, management, analysis, or interpretation of the data; preparation, review, or approval of the manuscript; decision to submit the manuscript for publication.

\section{Authors' contributions}

RG conceived of the study, created its design, wrote the manuscript, and performed the statistical analysis.

\section{Competing interests}

The authors declare that they have no competing interests.

Received: 24 June 2010 Accepted: 21 November 2011

Published: 21 November 2011

\section{References}

1. Broidy LM, Nagin DS, Tremblay RE, Bates JE, Brame B, Dodge KA, Fergusson D, Horwood JL, Loeber R, Laird R, Lynam DR, Moffitt TE, Pettit GS, Vitaro F: Developmental trajectories of childhood disruptive behaviors and adolescent delinquency: a six-site, cross-national study. Dev Psychol 2003, 39(2):222-245.

2. Kasen S, Cohen P, Skodol AE, Johnson JG, Smailes E, Brook JS: Childhood depression and adult personality disorder: alternative pathways of continuity. Arch Gen Psychiatry 2001, 58(3):231-236

3. Pollack MH, Otto MW, Sabatino S, Majcher D, Worthington JJ, McArdle ET, Rosenbaum JF: Relationship of childhood anxiety to adult panic disorder: correlates and influence on course. Am J Psychiatry 1996, 153(3):376-381.

4. Pine DS, Cohen E, Cohen P, Brook J: Adolescent depressive symptoms as predictors of adult depression: moodiness or mood disorder? Am J Psychiatry 1999, 156(1):133-135.
5. Pine DS, Goldstein RB, Wolk S, Weissman MM: The association between childhood depression and adulthood body mass index. Pediatrics 2001, 107(5):1049-1056.

6. Johnson JG, Cohen P, Kasen S, Brook JS: Eating disorders during adolescence and the risk for physical and mental disorders during early adulthood. Arch Gen Psychiatry 2002, 59(6):545-552.

7. Islam S, Gutin B, Treiber F, Hobbs G, Kamboh I, Lopes-Virella M: Association of apolipoprotein A phenotypes and oxidized low-density lipoprotein immune complexes in children. Arch Pediatr Adolesc Med 1999. 153(1):57-62.

8. Tran Minh NN, He Q, Edelman K, Olander RM, Viljanen MK, Arvilommi H, Mertsola J: Cell-mediated immune responses to antigens of Bordetella pertussis and protection against pertussis in school children. Pediatr Infect Dis J 1999, 18(4):366-370.

9. Zhong NS: New insights into risk factors of asthma. Respirology 1996, 1(3):159-166.

10. Cohen P, Pine DS, Must A, Kasen S, Brook J: Prospective associations between somatic illness and mental illness from childhood to adulthood. Am J Epidemiol 1998, 147(3):232-239.

11. Leadbitter P, Pearce N, Cheng S, Sears MR, Holdaway MD, Flannery EM, Herbison GP, Beasley R: Relationship between fetal growth and the development of asthma and atopy in childhood. Thorax 1999, 54(10):905-910.

12. von Mutius E: Paediatric origins of adult lung disease. Thorax 2001, 56(2):153-157.

13. Bayona M, Montealegre F, Gomes de Andrade VL, Trevino F: Prognostic factors of severe asthma in Puerto Rico. P R Health Sci J 2002, 21(3):213-219.

14. Kilpelainen M, Terho EO, Helenius H, Koskenvuo M: Home dampness, current allergic diseases, and respiratory infections among young adults. Thorax 2001, 56(6):462-467.

15. Vinuya RZ: Upper airway disorders and asthma: a syndrome of airway inflammation. Ann Allergy Asthma Immunol 2002, 88(4 Suppl 1):8-15.

16. Brown AS, Cohen P, Greenwald S, Susser E: Nonaffective psychosis after prenatal exposure to rubella. Am J Psychiatry 2000, 157(3):438-443.

17. Brown AS, Cohen P, Harkavy-Friedman J, Babulas V, Malaspina D, Gorman JM, Susser ES: A.E. Bennett Research Award. Prenatal rubella, premorbid abnormalities, and adult schizophrenia. Biol Psychiatry 2001, 49(6):473-486

18. Selten JP, Brown AS, Moons KG, Slaets JP, Susser ES, Kahn RS: Prenatal exposure to the 1957 influenza pandemic and non-affective psychosis in The Netherlands. Schizophr Res 1999, 38(2-3):85-91.

19. Craske MG, Poulton $R$, Tsao JC, Plotkin D: Paths to panic disorder/ agoraphobia: an exploratory analysis from age 3 to 21 in an unselected birth cohort. J Am Acad Child Adolesc Psychiatry 2001, 40(5):556-563.

20. Giulino L, Gammon P, Sullivan K, Franklin M, Foa E, Maid R, March JS: Is parental report of upper respiratory infection at the onset of obsessivecompulsive disorder suggestive of pediatric autoimmune neuropsychiatric disorder associated with streptococcal infection? J Child Adolesc Psychopharmacol 2002, 12(2):157-164.

21. Loiselle CR, Wendlandt JT, Rohde CA, Singer HS: Antistreptococcal, neuronal, and nuclear antibodies in Tourette syndrome. Pediatr Neurol 2003, 28(2):119-125.

22. Swedo SE: Pediatric autoimmune neuropsychiatric disorders associated with streptococcal infections (PANDAS). Mol Psychiatry 2002, 7(Suppl 2): S24-25.

23. Tucker DM, Leckman JF, Scahill L, Wilf GE, LaCamera R, Cardona L, Cohen P, Heidmann S, Goldstein J, Judge J, Snyder E, Bult A, Peterson BS, King R, Lombroso P: A putative poststreptococcal case of OCD with chronic tic disorder, not otherwise specified. J Am Acad Child Adolesc Psychiatry 1996, 35(12):1684-1691.

24. Lightman SL, Windle RJ, Ma XM, Harbuz MS, Shanks NM, Julian MD, Wood SA, Kershaw YM, Ingram CD: Hypothalamic-pituitary-adrenal function. Arch Physiol Biochem 2002, 110(1-2):90-93.

25. Shanks N, Lightman SL: The maternal-neonatal neuro-immune interface: are there long-term implications for inflammatory or stress-related disease? J Clin Invest 2001, 108(11):1567-1573.

26. Spolarics Z, Siddiqi M, Siegel JH, Garcia ZC, Stein DS, Denny T, Deitch EA: Depressed interleukin-12-producing activity by monocytes correlates with adverse clinical course and a shift toward Th2-type lymphocyte 
pattern in severely injured male trauma patients. Crit Care Med 2003, 31(6):1722-1729.

27. Lahey BB, Flagg EW, Bird HR, Schwab-Stone ME, Canino G, Dulcan MK, Leaf PJ, Davies M, Brogan D, Bourdon K, Horwitz SM, Rubio-Stipec M, Freeman DH, Lichtman JH, Shaffer D, Goodman SH, Narrow WE, Weissman MM, Kandel DB, Jensen PS, Richters JE, Regier DA: The NIMH Methods for the Epidemiology of Child and Adolescent Mental Disorders (MECA) Study: Background and Methodology. Journal of the American Academy of Child \& Adolescent Psychiatry 1996, 35(7):855-864.

28. Goodman SH, Hoven CW, Narrow WE, Cohen P, Fielding B, Alegria M, Leaf PJ, Kandel D, Horwitz SM, Bravo M, Moore R, Dulcan MK:

Measurement of risk for mental disorders and competence in a psychiatric epidemiologic community survey: the National Institute of Mental Health Methods for the Epidemiology of Child and Adolescent Mental Disorders (MECA) Study. Soc Psychiatry Psychiatr Epidemiol 1998, 33(4):162-173

29. Schwab-Stone ME, Shaffer D, Dulcan MK, Jensen PS, Fisher P, Bird HR, Goodman SH, Lahey BB, Lichtman JH, Canino G, Rubio-Stipec M, Rae DS: Criterion validity of the NIMH Diagnostic Interview Schedule for Children Version 2.3 (DISC-2.3). J Am Acad Child Adolesc Psychiatry 1996, 35(7):878-888

30. Shaffer D, Fisher P, Lucas CP, Dulcan MK, Schwab-Stone ME: NIMH Diagnostic Interview Schedule for Children Version IV (NIMH DISC-IV): description, differences from previous versions, and reliability of some common diagnoses. J Am Acad Child Adolesc Psychiatry 2000, 39(1):28-38.

31. Tedstone JE, Tarrier N: Posttraumatic stress disorder following medical illness and treatment. Clin Psychol Rev 2003, 23(3):409-448.

32. Timonen M, Viilo K, Vaisanen E, Rasanen P, Hakko H, Sarkioja T: Burden of illness and suicide in elderly people. Physical disease and depression are prevalent in elderly Finnish suicide victims. BMJ 2002, 325(7361):441.

33. Capuron L, Dantzer R: Cytokines and depression: the need for a new paradigm. Brain Behav Immun 2003, , 17 Suppl 1: S119-124.

34. Dantzer R: Cytokine-induced sickness behavior: mechanisms and implications. Ann N Y Acad Sci 2001, 933:222-234.

35. Levitan RD, Rector NA, Sheldon T, Goering P: Childhood adversities associated with major depression and/or anxiety disorders in a community sample of Ontario: issues of co-morbidity and specificity. Depress Anxiety 2003, 17(1):34-42.

36. Lieb R, Isensee B, Hofler M, Wittchen HU: Parental depression and depression in offspring: evidence for familial characteristics and subtypes? J Psychiatr Res 2002, 36(4):237-246.

37. Connell AM, Goodman SH: The association between psychopathology in fathers versus mothers and children's internalizing and externalizing behavior problems: a meta-analysis. Psychol Bull 2002, 128(5):746-773.

Pre-publication history

The pre-publication history for this paper can be accessed here: http://www.biomedcentral.com/1471-2458/11/878/prepub

doi:10.1186/1471-2458-11-878

Cite this article as: Goodwin: Association between infection early in life and mental disorders among youth in the community: a cross-sectional study. BMC Public Health 2011 11:878.

\section{Submit your next manuscript to BioMed Central and take full advantage of:}

- Convenient online submission

- Thorough peer review

- No space constraints or color figure charges

- Immediate publication on acceptance

- Inclusion in PubMed, CAS, Scopus and Google Scholar

- Research which is freely available for redistribution

Submit your manuscript at www.biomedcentral.com/submit
Biomed Central 